\title{
REVISTAMARACANAN
}

Artigo

\section{Crítica à utopia/crítica à modernidade: sobre o alcance e as limitações da teoria da história de Reinhart Koselleck diante da atual crise do tempo}

Criticism of utopia/criticism of modernity: on the scope and limitations of Reinhart Koselleck's theory of history in the face of the current crisis of time

Marcelo Durão Rodrigues da Cunha*

Instituto Federal do Espírito Santo Itapina, Espírito Santo, Brasil

Júlia Freire Perini ${ }^{* *}$

Secretaria Estadual de Educação do Espírito Santo Vitória, Espírito Santo, Brasil

Recebido em: 24 jul. 2020.

Aprovado em: 27 mar. 2021.

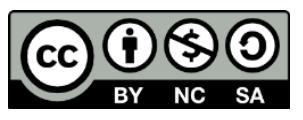

Essa pesquisa contou com o aporte financeiro da Foundation for Polish Science (FNP), Team Program, the "Core Concepts of Historical Thinking" Project, financiamento no POIR.04.04.00-00-5C1E17-00.

* Professor do Instituto Federal do Espírito Santo e pesquisador de Pós-Doutorado pela Adam Mickiewicz University. (marceloduraocunha@gmail.com)

(1) https://orcid.org/0000-0002-6952-4860 (6) http://lattes.cnpq.br/9305916400288656

** Pesquisadora de Pós-Doutorado pela Adam Mickiewicz University e doutora em história pela Universidade Federal do Espírito Santo. (juliafreireperini@gmail.com)

(1) https://orcid.org/0000-0001-6585-6836 (6) http://lattes.cnpq.br/3416308333458306 


\title{
Resumo
}

Este artigo tem o objetivo de esclarecer o lugar ocupado pela crítica à utopia nos escritos teóricos de Reinhart Koselleck, buscando explorar aquilo que é entendido pelo historiador alemão como o fenômeno de temporalização da utopia. Para tanto, procuramos em um primeiro momento esclarecer o significado da noção de temporalização na obra desse autor, a entendendo como parte central para a compreensão da teoria koselleckiana dos tempos históricos e de sua crítica à modernidade. Em seguida, analisamos a importância assumida pela crítica à utopia no trabalho do historiador desde a escrita da obra Crítica e crise (1959), a compreendendo como parte de sua tentativa de apreensão dos fenômenos da despolitização e do surgimento das modernas filosofias da história no século XVIII europeu. Finalmente, o trato com esses pontos é o que nos permite desenvolver os dois objetivos gerais pretendidos com a escrita do presente artigo: demonstrar a centralidade da noção de utopia - e de sua crítica - nos escritos teóricos de Koselleck e discutir em que medida as soluções empreendidas pelo historiador ao esgotamento da lógica moderna de interpretação utópica da mudança histórica se constituem como respostas plausíveis para se superar a crise contemporânea do tempo, sobretudo, nas periferias do mundo ocidental.

Palavras-chave: Reinhart Koselleck. Utopia. Modernidade.

\begin{abstract}
This article aims to clarify Reinhart Koselleck's criticism to the idea of modern utopianism, by seeking to analyze what the historian understands as the temporalization of utopia. Therefore, we first seek to explain the meaning of Koselleck's idea of temporalization, while framing it as a central feature of his theory of the historical times and of his criticism on Western modernity. Secondly, we argue that Koselleck's critical position vis-à-vis political utopianism was already present in his Critique and crisis (1959), specially as his means of understanding the emergence of the modern philosophies of history and as his way of overcoming the depoliticisation phenomenon which was regarded by him as a feature of the Enlightenment thinking of eighteenth-century Europe. Finally, the clarification of these issues allows us to develop the two general objectives intended with the writing of this article: to demonstrate the centrality of utopia criticism in Koselleck's theoretical writings and to discuss to what extent the solutions undertaken by the historian to the exhaustion of the modern utopian interpretation of historical change are plausible responses to overcome the contemporary crisis of time, especially in the so-called peripheries of the Western world.
\end{abstract}

Keywords: Reinhart Koselleck. Utopia. Modernity. 


\section{Introdução}

É consensual entre os mais distintos teóricos e críticos da modernidade a ideia de que o advento da experiência moderna do mundo ocidental foi acompanhado por uma otimista crença na noção de temporalidade e no próprio significado adquirido pelo conceito de história. Impulsionados pelo que passava a ser entendido como a abertura a uma "nova era", entre os séculos XVIII e XIX os sujeitos ocidentais teriam passado a depender cada vez mais de sua relação com o tempo, de modo que o próprio significado da história teria incorporado, aos poucos, o sentido de uma grande - e acelerada - marcha da humanidade em direção aos rumos do progresso. ${ }^{1}$

De modo a melhor compreender o significado cultural dessa nova característica adquirida pela experiência temporal e pelo conceito de história desde o século XVIII, muitos foram os estudos que nas últimas décadas se debruçaram sobre os contornos das modernas filosofias da história e da própria ciência histórica no ocidente. De toda forma, não seria um exagero afirmar que poucos autores trouxeram uma leitura tão profunda e produziram tantas ferramentas analíticas de compreensão desse fenômeno de mudança no significado do tempo e da história nos últimos séculos quanto o historiador alemão Reinhart Koselleck (1923-2006).

Em sua história conceitual e em suas reflexões teóricas a respeito dos contornos da ideia de modernidade, Koselleck foi capaz de produzir uma verdadeira inflexão na maneira de se compreender a relação entre as estruturas sócio-históricas, a linguagem e a experiência temporal dos homens europeus. Sua teoria dos "estratos do tempo" (Zeitschichten) e sua problematização do tipo singular de história produzido a partir da experiência temporal moderna o situaram como uma importante referência não apenas nos territórios de língua alemã e na Europa, como também no Brasil e em outros países latino-americanos. A grande quantidade de obras e textos do historiador traduzidos para o português nos últimos anos, além da expansão de projetos como o Iberconceptos ${ }^{2}$ demonstram o nível de importância adquirido pela história

\footnotetext{
1 KOSELLECK, Reinhart, MEIER, Christian, GÜNTHER, Horst \& ENGELS, Odilo. O conceito de História. Autêntica, Belo Horizonte, 2013.

2 O Projeto Iberconceptos reúne desde 2004 pesquisadores de países como Argentina, Brasil, Peru, México, Uruguai, Venezuela, Portugal, Espanha e diversas nações caribenhas com o objetivo de estudar, por meio de conceitos, linguagens e metáforas políticas, o significado da experiência moderna nos países iberoamericanos entre os séculos XVIII e XIX. O Iberconceptos ocupa-se, portanto, em estabelecer as bases para uma história conceitual comparada no mundo ibero-americano, publicando obras coletivas como os dois tomos do Diccionario político y social del mundo iberoamericano (2009, 2014). Maiores informações sobre o Iberconceptos podem ser encontradas em: http://www.iberconceptos.net/
} 
conceitual e pela crítica koselleckiana da modernidade no Brasil e na América Latina como um todo. ${ }^{3}$

Como notado recentemente por Frank Ankersmit, uma das razões para o sucesso da proposta koselleckiana nas ditas "periferias" do mundo ocidental se deve ao fato de sua teoria dos estratos do tempo levar a um tipo de reflexão ontológica capaz de desconstruir aspectos do fenômeno da simultaneidade do não-simultâneo e de minar velhas, estáticas e, sobretudo, eurocêntricas, maneiras de se interpretar a temporalidade e os muitos sentidos possíveis de serem atribuídos à história. ${ }^{4}$ Mas como exatamente Koselleck foi capaz de instrumentalizar a sua teoria dos estratos do tempo de modo a produzir esse tipo de crítica à forma moderna de se conceber a temporalidade?

A resposta reside tanto na ampla - e já bastante conhecida - tese koselleckiana sobre o alvorecer dos tempos modernos, quanto em seu entendimento do significado do fenômeno de temporalização da experiência humana a partir do advento da modernidade. Além de ser revelador do caráter eminentemente cético da agenda teórica do historiador, ${ }^{5} \circ$ trato de Koselleck com o fenômeno em questão compõe parte central de outro importante constituinte de sua teoria da história: a sua crítica ao encurtamento do espaço de experiência dos sujeitos modernos em nome da abertura a horizontes de expectativa cada vez mais orientados à futuridade da experiência com o tempo.

Discernível principalmente a partir de uma compreensão das mudanças sofridas pelos principais conceitos surgidos entre 1750 e 1850 - o Sattelzeit (tempo de cela, período limiar ou tempo limite) - no espaço de língua alemã, essa desconstrução da maneira eminentemente moderna de se pensar o tempo é o mote da análise koselleckiana de termos como Estado, progresso, história e - talvez de um dos mais importantes para o entendimento de sua teoria da história - o conceito de utopia.

Figurando como o ponto de partida de obras como Crítica e Crise (1959) ${ }^{6}$ e de alguns dos seus escritos teóricos dos anos 1970 e 1980, o conceito de utopia e a crítica estabelecida por Koselleck à ressignificação de seu sentido na era moderna é central não apenas para o entendimento da referida ontologia do historiador, como também para a abertura de novas

\footnotetext{
${ }^{3}$ FERES JÚNIOR, João; JASMIN, Marcelo G. Introdução: trajetórias e contatos da história conceitual In: FERES JÚNIOR, João; JASMIN, Marcelo G. (Org.). História dos Conceitos: diálogos transatlânticos. Rio de Janeiro: Edições Loyola, 2007, p. 14.

4 ANKERSMIT, Frank. Koselleck on 'histories' versus 'History' or: historical ontology versus historical epistemology. 2nd INTH Conference: The Practical Past, UFOP, 2016, p. 13-14.

${ }^{5}$ Essa é uma classificação oferecida pelo sociólogo Helmut Schelsky que definia Koselleck e todo um grupo de autores que cresceram no cenário alemão do pós-1945 (após as experiências do nazismo, da juventude hitlerista, da guerra, do cativeiro, da defesa contra os bombardeios aliados e da derrota de 1945), como pertencentes a uma "geração cética", isto é, intelectuais que, marcados por uma série de traumas geracionais, assumiram posições críticas em relação à ideologia política e a projetos de desenvolvimento social de longo prazo (SCHELSKY, Helmut. Die skeptische Generation: eine Soziologie der deutschen Jugend. Eugene Diederichs, 1957).

${ }^{6}$ KOSELLECK, Reinhart. Crítica e crise: uma contribuição à patogênese do mundo burguês. Rio de Janeiro: Eduerj, 1999.
} 
possibilidades de interpretação da cultura historiográfica surgida na consciência histórica dos centros e das periferias do Ocidente nos últimos séculos.

Dada a centralidade do conceito na obra do autor dos Geschichtliche Grundbegriffe, nas páginas que seguem visamos esclarecer o lugar ocupado pela crítica da utopia nos escritos teóricos do historiador, buscando explorar, sobretudo, aquilo que é entendido por Koselleck como o fenômeno de temporalização da utopia na modernidade. Antes de analisar o significado desse fenômeno na obra do historiador, entretanto, é necessário esclarecer a já referida noção de temporalização como parte constituinte da teoria koselleckiana da modernidade.

O trato com esses pontos permitirá que se contemplem os dois objetivos gerais pretendidos com a escrita do presente artigo: demonstrar a centralidade da noção de utopia e de sua crítica - nos escritos teóricos de Koselleck e discutir em que medida as soluções empreendidas pelo historiador ao esgotamento da lógica moderna de interpretação utópica da mudança histórica se constituem como respostas plausíveis para se superar, sobretudo, nas periferias do mundo ocidental o que é definido pela historiografia das últimas décadas como a crise contemporânea do tempo.

\section{Modernidade e temporalização}

Figurando como um elemento chave para o entendimento de sua tese sobre a modernidade, a noção de tempo histórico pode também ser considerada como o ponto nevrálgico da própria teoria da história desenvolvida por Koselleck. Situando a si próprio como herdeiro do interesse heideggeriano pelos temas da temporalidade e da historicidade, ao contrário do autor de Ser e tempo, ${ }^{7}$ todavia, Koselleck pretendia deixar de lado o problema ontológico para debruçar-se sobre os constituintes antropológicos da ideia de tempo histórico.

Prova desse seu esforço de aproximação com a antropologia era a ênfase conferida pelo autor às já mencionadas noções de espaço de experiência e horizonte de expectativa, categorias analíticas capazes de transpor a maneira natural de se mensurar o tempo e de fornecer aos historiadores as bases para a compreensão das mais variadas formas de expressão da temporalidade pelos agentes históricos. ${ }^{8}$

Tratando-se de categorias formais - e não "das histórias em si mesmas" -, experiência e expectativa se encontrariam no cerne de quaisquer ações ou interações sócio-históricas, sendo capazes de delinear e de estabelecer aquilo que o historiador compreendia como as "condições das histórias possíveis": "Assim, nossas duas categorias indicam a condição humana universal; ou, se assim o quisermos, remetem a um dado antropológico prévio, sem o qual a história não

\footnotetext{
7 HeIDEgGer, M. Ser e tempo. Petrópolis, RJ: Vozes, 2013.

8 DUARTE, J. A. D. Tempo e Crise na Teoria da Modernidade de Reinhart Koselleck. História da Historiografia, v. 8, p. 70-90, 2012, p. 72.
} 
seria possível, ou não poderia sequer ser imaginada". ${ }^{9}$ Esse recurso a categorias dotadas de um alto grau de generalidade era a estratégia metodológica adotada por Koselleck com o intuito de superar tanto as armadilhas da relatividade historicista, quanto as pretensões absolutas existentes nas antigas filosofias da história. ${ }^{10}$

Além de demonstrar os seus débitos em relação à tradição neokantiana de reflexão histórico-filosófica, essas categorias formais desenvolvidas por Koselleck representavam o ponto meta-histórico a partir do qual ele acreditava poder desenvolver a sua própria teoria dos tempos históricos. Mas se em sua universalidade elementar, experiência e expectativa seriam capazes de revelar a expressão do tempo histórico, como exatamente poderiam os historiadores apreender metodologicamente essa manifestação histórico-antropológica da temporalidade?

A resposta se encontrava na linguagem ou mais especificamente nos conceitos fundamentais presentes no imaginário sócio-político de indivíduos e de sociedades historicamente constituídas. Seria nos conceitos e na história de seu desenvolvimento que a articulação entre experiência e expectativa far-se-ia sentir de maneira mais evidente, cabendo aos historiadores compreender a evolução e a dinâmica da disputa por significados através de uma combinação entre essa história conceitual e um tipo renovado de história social:

$\mathrm{Na}$ exegese do texto, o interesse especial pelo emprego de conceitos políticosociais e a análise de suas significações ganham, portanto, uma importância de caráter social e histórico. Os momentos de duração, alteração e futuridade contidos em uma situação política concreta são apreendidos por sua realização no nível linguístico. Com isso, ainda falando de modo geral, as situações sociais e respectivas alterações já são problematizadas no próprio instante dessa realização linguística. ${ }^{11}$

Característica dos seus vínculos com a hermenêutica filosófica de Hans-Georg Gadamer, essa ênfase conferida por Koselleck à linguagem e à história dos conceitos era a maneira pela qual o historiador acreditava ser capaz de apreender a expressão semântica da temporalidade pelos agentes históricos.

Estabelecendo essas balizas meta-históricas e epistemológicas, Koselleck parecia assim, finalmente disposto a demonstrar empiricamente uma das teses principais presente nos seus escritos teóricos dos anos 1970: a ideia de que a era moderna se caracterizaria como um momento em que a diferença entre experiência e expectativa teria aumentado progressivamente, estabelecendo uma distância inédita entre novas expectativas e as experiências adquiridas até então. ${ }^{12}$

\footnotetext{
9 KOSELLECK, Reinhart. Futuro passado: contribuição à semântica dos tempos históricos. Rio de Janeiro: Contraponto, Ed. PUC-Rio, 2006, p. 308.

10 OLSEN, Niklas. History in the Plural: an introduction to the work of Reinhart Koselleck. New York: Berghahn Books, 2012, p. 68.

${ }^{11}$ KOSELLECK, Reinhart. Futuro passado... Op cit., p. 101.

12 Ibidem, p. 314.
} 
A fim de indicar a especificidade da temporalidade contida nessa tensão entre experiência e expectativa em tempos modernos, Koselleck apresentava uma série de evidências discerníveis a partir do ponto de vista "dos dados objetivos" da história social, assim como através de um estudo do desenvolvimento semântico da linguagem político-social europeia dos cinco últimos séculos.

Para o historiador, evidências de uma relação harmônica entre experiências passadas e expectativas vindouras na Europa pré-moderna eram identificáveis, sobretudo, na maneira pela qual os indivíduos organizavam a sua vida cotidiana e a sua forma de verbalizar a realidade. Cerceado pelos limites da natureza e pelo modo tipicamente cristão de se conceber o mundo histórico, os homens e mulheres europeus pautava o ritmo de suas vidas pelos ciclos das colheitas, pela duração dos dias e das noites, pelo decurso geracional, pela regularidade das estações do ano e em especial pela expectativa de salvação após a chegada do fim do mundo.

Incapazes de transpor as limitações impostas pela natureza e pela escatologia cristã, os indivíduos viviam sob a égide de um tipo "estático" de tempo histórico, quando passado e futuro pareciam habitar de forma contígua a experiência de vida no presente:

[...] as expectativas que eram ou que podiam ser alimentadas (...) eram inteiramente sustentadas pelas experiências dos antepassados, que passavam a ser também as dos descendentes. Quando alguma coisa mudava, tão lenta e vagarosa era a mudança que a ruptura entre a experiência adquirida até então e uma expectativa ainda por ser descoberta não chegava a romper o mundo da vida que se transmitia. ${ }^{13}$

Enquanto a doutrina cristã dos últimos fins impunha limites intransponíveis ao horizonte de expectativa - ou seja, até meados do século XVII, aproximadamente -, o futuro permanecia atrelado ao passado e as perspectivas que se projetavam para além de toda experiência vivida não se referiam a este mundo. Logo, em um cenário de transição quase perfeita das experiências passadas para as expectativas vindouras, era comum não só a formulação de previsões a respeito do fim dos tempos, como também a realização de prognósticos no campo da política e da escrita histórica. Sem grandes alterações no âmbito da vida cotidiana, não seria difícil antever as realizações futuras, tampouco extrair da história exemplos morais capazes de orientar a conduta dos sujeitos no presente.

De todo modo, Koselleck percebia que esse tipo de relação dos indivíduos com o tempo se alteraria drasticamente a partir de uma série de mudanças ocorridas entre os séculos XVI e XVIII no âmbito da experiência de vida da burguesia europeia. Em especial devido ao avanço da ciência e da técnica, às guerras religiosas, à descoberta do Novo Mundo - com populações vivendo em diferentes fases de desenvolvimento -, além da dissolução do mundo feudal pela indústria e pelo capital, aquela maneira harmônica de se experimentar o tempo passou aos poucos a dar lugar a um novo e mais dinâmico tipo de expressão da temporalidade. ${ }^{14}$

\footnotetext{
13 Op. cit., p. 315.

${ }^{14}$ KOSELLECK, Reinhart. Futuro passado... Op. cit., p. 278.
} 
A técnica e os desenvolvimentos científicos pareciam ter minado por completo os antigos limites estabelecidos pela natureza e pelo próprio Deus cristão à ação humana. Assim, aquilo que antes havia se configurado como uma forma quase estática e imperceptível de relação com o tempo foi lentamente se convertendo em uma verdadeira obsessão:

Praticamente ninguém conseguiu escapar ao conceito de tempo e ao que ele era capaz de oferecer. O "tempo" exerceu influência sobre o conjunto da linguagem, e pelo menos a partir da Revolução Francesa deu colorido a todo o vocabulário político e social. Desde então quase não existe um conceito central da teoria política ou dos programas sociais que não contenha um coeficiente de variação temporal, sem o qual nada mais pode ser reconhecido, nada pode ser pensado ou argumentado, e sem o qual a força dos conceitos ficaria perdida. ${ }^{15}$

Esse processo de crescimento de importância da ideia de tempo no imaginário e no próprio vocabulário sociopolítico europeu era entendido por Koselleck como o fenômeno da temporalização (Verzeitlichung). ${ }^{16}$ As expectativas que anteriormente se projetavam para o além apocalíptico passaram a centrar-se nas potencialidades deste mundo, gerando o tipo acelerado de entendimento da realidade expresso através dessa centralidade adquirida pelo tempo na era moderna:

\begin{abstract}
Apesar de podermos descrever esse processo como secularização, o termo mais adequado seria "temporalização". Com isso, teríamos encontrado um primeiro atalho para a nossa pergunta sobre a relação entre aceleração e secularização. Pois se existe uma experiência temporal histórica, inerente ao mundo, que seja distinta dos ritmos temporais determinados pela natureza, essa, sem dúvida, seria a experiência da aceleração, em virtude da qual o tempo histórico se qualifica como tempo específico produzido pelo ser humano. A experiência temporal, que sempre é determinada pela natureza, só pode ser uma experiência especificamente histórica por meio da conscientização da aceleração (ou da retardação que lhe corresponde). ${ }^{17}$
\end{abstract}

O antigo decurso único de um tempo estático transformou-se em um dinamismo de estratos múltiplos vividos simultaneamente. Da escatologia, que antigamente pregava o fim da história do mundo, passou-se ao progresso, que se tornou um auxiliar fundamental da realização secular dos postulados cristãos até a liberdade vindoura. A história - que antigamente ensinava e permitia a realização de prognósticos - incorporou o sentido de um "singular coletivo" expresso pelo conceito de Geschichte, em alemão -, passando doravante a significar tanto os

15 Op. cit., p. 296.

16 Além da temporalização, Koselleck descreveu outros três teoremas da modernização associados ao Sattelzeit: 1) a politização, que permite compreender como os conceitos já existentes ou recém-criados relacionados aos posicionamentos sociais passaram a expressar projetos ou orientar a dinâmica política; 2) a ideologização, que está relacionada à apreensão das transformações sociais que ocorreram com muita rapidez, ligando-se, assim, à criação de grandes conceitos abstratos ou singulares coletivos; e 3) a democratização, que remete à ideia de familiarização de conceitos que antes estavam encastelados nos livros ou aprisionados em determinados estamentos da sociedade e que passaram a ser de uso mais comum com a ampliação do âmbito dos grupos sociais que passam a os utilizar (KOSELLECK, Reinhart. Un texto fundamental de Reinhart Koselleck: la introducción al Diccionario Histórico de Conceptos Político-Sociales Básicos en Lengua Alemana, seguida del prólogo de dicha obra (traduzido por Luis Fernández Torres). Anthropos, n, 223, Barcelona, 2009, p. 6-10).

17 KOSELLECK, Reinhart. Estratos do tempo: estudos sobre a história. Contraponto: Puc Rio, Rio de Janeiro, 2014, p. 171. 
relatos a respeito do passado, quanto o processo de desenvolvimento do todo da humanidade através do tempo. ${ }^{18}$

Esse processo de dinamização do tempo como a força propulsora da própria história passou a abarcar toda a experiência dos indivíduos europeus principalmente após a segunda metade do século XVIII. A história foi temporalizada, no sentido de que, graças ao correr do tempo, a cada momento, e com o crescente distanciamento, ela se modificava também no passado, revelando distintos tipos de verdade.

Temporalizados e voltados para o porvir, para além do progresso e da história, outros termos passaram também a traduzir essa nova relação entre experiência e expectativa característica da era moderna. Por isso, não seria exagerado afirmar que o dicionário dos conceitos e boa parte da Historik koselleckiana, possuíam o intuito principal de compreender os efeitos desse processo de temporalização operado a partir da experiência moderna. ${ }^{19}$

Como visto, através dessa semântica sócio-política fundamental, Koselleck conferia um destaque especial em sua teoria da história à ideia de utopia: o conceito que - como uma resposta ao absolutismo - teria inaugurado "o processo dos tempos modernos". ${ }^{20}$ É sobre esse lugar ocupado pelo conceito de utopia na obra de Koselleck que trataremos a seguir.

\section{Crítica e crise: a patogênese do mundo burguês ou a utopia como despolitização}

Central em sua crítica da modernidade - além de ser um dos 122 léxicos sócio-políticos escolhidos para figurar nos Geschichtliche Grundbegriffe ${ }^{21}$ - a preocupação com a questão da utopia é algo presente no trabalho de Koselleck ao menos desde a publicação do seu primeiro texto acadêmico: a tese Crítica e crise de 1959. Conforme revelado pelo autor no prefácio à tradução do texto em língua inglesa, Crítica e crise representava "uma tentativa de examinar as pré-condições históricas do Nacional-socialismo alemão, cuja perda de senso de realidade e auto exaltação utópica (grifo nosso) havia resultado em crimes até então sem precedentes". Além disso, haveria a sua preocupação com o contexto da Guerra Fria já que, em suas palavras: "eu almejava investigar as suas raízes utópicas (grifo nosso) que pareciam impedir que as duas superpotências se reconhecessem mutuamente como oponentes". ${ }^{22}$

\footnotetext{
18 KOSELLECK, Reinhart. Futuro passado... Op. cit., p. 236.

19 JUNG, Theo. Das Neue der Neuzeit ist ihre Zeit: Reinhart Kosellecks Theorie der Verzeitlichung und ihre Kritiker. Moderne Kulturwissenschaftliches Jahrbuch, n. 6, 2011, p. 174-175.

20 KOSELLECK, Reinhart. Crítica e crise... Op. cit., p. 160.

21 Presente no sexto volume do léxico, publicado em 1990, a escrita da história do conceito de utopia ficou a cargo do historiador bávaro Lucian Hölscher. Cf. HÖLSCHER, Lucian. Utopie. In: BRUNNER, Otto; CONZE, Werner; KOSELLECK, Reinhart. Geschichtliche Grundbegriffe. Historisches Lexikon zur politisch-sozialen Sprache in Deutschland, v. 6, 1990.

22 REINHART, Koselleck. Critique and Crisis: Enlightenment and the Pathogenesis of Modern Society. The MIT Press, Cambridge, Massachusetts, 1988.
} 
Equacionando o conceito de utopia a uma espécie de quimera antirrealista que teria levado a civilização Ocidental às catástrofes do século XX, Koselleck deixava claro que a sua tese tinha o objetivo de investigar as raízes dessa inclinação moderna às assim chamadas armadilhas do utopismo e, em última instância, à sua mais bem definida formulação ideológica, isto é, as modernas filosofias da história:

Assim como o globo terrestre foi unificado pela primeira vez pela sociedade burguesa, a crise atual também se desenrola no horizonte de um autoentendimento histórico-filosófico, predominantemente utópico. Este autoentendimento é utópico porque destina o homem moderno a estar em casa e em parte alguma. A história transbordou as margens da tradição e submergiu todas as fronteiras. ${ }^{23}$

Situando as origens dessa verdadeira "patologia" moderna na Europa do século XVIII, o historiador se concentrava em desvelar os contornos daquela que teria sido a pretensão burguesa em criar uma lógica utópica totalizante para as suas filosofias do progresso em consonância com o ideário iluminista. ${ }^{24}$ Alijada do poder pelo Estado absolutista no contexto das guerras civis religiosas, a intelectualidade burguesa teria sedimentado o terreno de um tipo específico de crítica moral ao status quo político europeu do período. Distante da práxis política, a burguesia ascendente teria construído aquilo que Koselleck denominava como uma espécie de mundo moral que, a partir de uma nascente - livre de responsabilidades e cada vez mais influente - esfera privada burguesa, começava a erigir críticas racionalmente orientadas aos fundamentos do Estado absolutista.

Longe de ter produzido diagnósticos capazes de transpor a crise do Estado e da esfera pública, entretanto, a crítica praticada pela inteligência burguesa obscureceu a realidade e, através da construção de uma série de imagens histórico-filosóficas do futuro, resultou no esmorecimento dos eventos cotidianos e do próprio sentido da vida política:

\begin{abstract}
Assim, a crise encaminhou-se, ainda mais desimpedidamente, em direção a uma decisão inesperada. Esta dialética funda-se no modo específico da crítica que se exercia no século XVIII e que Ihe concedeu o seu nome. A crítica praticada pela inteligência burguesa determinou o papel da burguesia ascendente e englobou o novo mundo. ${ }^{25}$
\end{abstract}

Sem tornar-se consciente dessa transformação, a intelectualidade burguesa moralizou a história, convertendo-a em um processo dotado de significado próprio. Inaugurava-se, nas palavras do historiador, o "alto tribunal da razão" através do qual a nova elite ascendente julgava-se capaz de interpretar todas as esferas da vida. Para Koselleck, foi justamente o fermento da crítica o que possibilitou o surgimento dessa filosofia burguesa da história que, não

\footnotetext{
${ }^{23}$ KOSELLECK, Reinhart. Crítica e crise: uma contribuição à patogênese do mundo burguês. Rio de Janeiro: Eduerj, 1999, p. 9.

${ }^{24} \mathrm{ABREU}$, Cesaltina. A transformação da história em processo: Da perspectiva utópica da filosofia da história à Revolução Francesa de Koselleck. Mulemba, Luanda, v. 6, n. 11, p. 351-367, 2016, p. 351.

25 KOSELLECK, Reinhart. Crítica e crise: uma contribuição à patogênese do mundo burguês. Rio de Janeiro: Eduerj, 1999, p. 13-14.
} 
reconhecendo a autonomia dos domínios por ela criticados, procurou apoiar-se no amanhã, negligenciando o hoje e as complexidades da vida política do presente:

Para fazer valer seus direitos, a crítica do século XVIII teve que se tornar utópica. Finalmente, o último objeto da crítica, o Estado absolutista, contribui, à sua maneira, para estabelecer a visão utópica que a burguesia tinha da história. ${ }^{26}$

Foi, portanto, essa experiência de crítica apolítica ao absolutismo o solo fértil a partir do qual a visão eminentemente utópica da história tomou corpo entre os membros da burguesia letrada na Europa setecentista. Por isso é possível concordar com Victor Gourevitch quando ele destaca que é o fenômeno da despolitização - fomentado pelo entusiasmo iluminista da nascente burguesia europeia - o que mais preocupava Koselleck em sua análise das utopias modernas em Crítica e crise. ${ }^{27}$

Vivendo o que acreditava serem as drásticas consequências desse processo, nos anos 1950 o historiador alemão parecia não mais capaz de conceber a utopia como uma alternativa política viável. Conforme lembrado por Gourevitch, para Koselleck o utopismo político seria tão contraditório quanto o ceticismo dogmático, tendo se desenvolvido nos três últimos séculos como uma espécie de reino da hipocrisia, irresponsável e desprovido de qualquer autoconsciência política. ${ }^{28}$ Por isso, Crítica e crise buscava em um sentido amplo analisar como o utopismo burguês foi racionalizado, radicalizado e transmutado à nova filosofia da história na era moderna:

Quando nossa investigação tiver atingido sua meta, a dependência e o entrelaçamento, recíprocos da crise e da filosofia da história - e, por que não, sua identidade - terão se tornado visíveis em alguns pontos de partida do século XVIII. O utopismo originou-se de um mal-entendido em relação à política, malentendido que foi condicionado historicamente e, em seguida, fixado pela filosofia da história (...) A estrutura política do Estado absolutista e o desenvolvimento do utopismo são um processo complexo, no qual se inicia a crise política do presente. ${ }^{29}$

Compreendendo as raízes desse processo, Koselleck acreditava ser capaz de conter a separação entre moral e política engendrada pela filosofia burguesa da história, buscando, de igual modo, reaver a importância da política enquanto tarefa primordial da existência humana. Mas se é clara a associação estabelecida pelo historiador entre a ideia de utopia e o fenômeno de despolitização na modernidade, em Crítica e crise Koselleck lidava apenas com a gênese desse processo, não chegando a lidar de forma direta com as consequências do utopismo para a experiência histórica europeia dos séculos subsequentes.

26 Op. cit., p. 15.

27 GOUREVITCH, Victor. Foreword. In: REINHART, Koselleck. Critique and Crisis: Enlightenment and the Pathogenesis of Modern Society. The MIT Press, Cambridge, Massachusetts, 1988, p. IX.

28 Ibidem, p. VIII.

${ }^{29}$ KOSELLECK, Reinhart. Crítica e crise: uma contribuição à patogênese do mundo burguês. Rio de Janeiro, Eduerj, 1999, p. 17. 
Demoraria, portanto, pouco mais de duas décadas para que o historiador tratasse diretamente de tal temática, quando ele refletiria novamente sobre o conceito de utopia em alguns escritos teóricos dos anos 1980, circunscrevendo-os desta vez à sua teoria da história e à sua crítica da modernidade. É sobre os textos em questão que trataremos a seguir.

\section{A irrupção do futuro na utopia ou a incorporação da utopia na filosofia da história}

Publicado originalmente em $1982,^{30}$ o texto intitulado A temporalização da utopia representava uma tentativa da parte de Koselleck de elucidar e de estabelecer, pela primeira vez, a relação entre dois elementos que, como visto, estavam presentes nos seus escritos teóricos desde o início de sua carreira: a utopia e o fenômeno da temporalização. Conforme esclarecido pelo próprio autor, a sua investigação não tinha o objetivo de definir a utopia no seio de uma história dos gêneros literários, tampouco de realizar uma história do conceito em si, mas sim de analisar aquele que seria o processo de incorporação da utopia pela filosofia da história com o seu consequente processo de temporalização a partir do advento da modernidade.

Para tanto, Koselleck analisava a obra de dois autores que, apesar de um tanto distintos e contraditórios em termos de contexto e de estilo (e que mesmo não tendo classificado a si próprios como "utopistas"), exemplificavam dois lados opostos do fenômeno em questão. 0 primeiro era Louis-Sébastien Mercier, autor francês setecentista que em 1770 escreveu o romance futurístico $O$ ano 2440. O segundo era Carl Schmitt, jurista alemão que em 1918 publicou Die Buribunken, uma sátira política e histórico-filosófica de sua época.

Testemunha das mudanças políticas vividas pela Europa e pelo Novo Mundo na segunda metade do século XVIII, a obra de Mercier era vista pelo autor como uma das mais claras expressões da transição pragmática experimentada pelo iluminismo francês nas décadas anteriores à revolução de 1789. De todo modo, não era tanto o trabalho político do intelectual francês - depreciado e tido à sua época como caricato - o que mais interessava o historiador, mas a sua atuação como romancista e, sobretudo, a sua contribuição para aquilo que Koselleck identificava como uma "verdadeira virada na história dos gêneros". ${ }^{31}$

Nascido da tentativa de transcrever um sonho, O ano 2440 era a visão de Mercier a respeito da cidade de Paris em um futuro distante. Descrevendo as características de uma época qualitativamente superior, Mercier inaugurava, nas palavras de Koselleck, uma "utopia futurística precisa". Mas se $O$ ano 2440 seguramente não foi o primeiro romance utópico já

\footnotetext{
30 O texto foi publicado pela primeira vez no terceiro volume de Utopieforschung: interdisziplinäre Studien zur neuzeitlichen Utopie, sendo republicado em 2000 na coletânea Zeitschichten. Esta última, incluindo o texto A temporalização da utopia, foi traduzida para o português por Markus Hediger e publicado pelas editoras Contraponto e Puc RJ com o título de Estratos do Tempo (2014).

${ }^{31}$ KOSELLECK, Reinhart. Estratos do tempo: estudos sobre a história. Contraponto: Puc Rio, Rio de Janeiro, 2014, p.123.
} 
escrito, Koselleck era categórico em afirmar que o livro de Mercier inovava por introduzir, pela primeira vez, a dimensão temporal do futuro como meio da utopia:

No entanto, é claro que também os nenhures, os contramundos espaciais das antigas utopias podem ser lidos como visões potenciais do futuro (...) Mas o espaço de experiência das utopias existentes era primariamente espacial, e assim o era também seu modo de representação. Algum viajante desembarca em alguma costa estrangeira, transeuropeia, e ali descobre estados ideais ou sociedades pré-estatais das mais diferentes ordens de grandeza. O descobridor volta para casa e narra como o contramundo é bem organizado e agradável. Dele, então, pode ser deduzido um futuro irreal ou até mesmo potencial para o próprio mundo (...) Isso mudou a partir de Mercier, e, podemos acrescentar, não por acaso. ${ }^{32}$

Além de turbulento em termos políticos, o contexto intelectual vivido por Mercier havia também sido marcado pelas viagens de exploração europeias que em meados dos anos 1770 já haviam mapeado e tornado conhecido aos olhos do velho mundo praticamente todos os cantos do globo terrestre. As possibilidades espaciais de situar as utopias na finitude da superfície do planeta haviam se esgotado, de modo que os espaços utópicos pareciam ter sido ultrapassados pela própria experiência humana.

Por isso, ao explorar a temática do futuro, o romance de Mercier encontrava uma espécie de espaço de desafogo no qual a imaginação fluía e se reproduzia infinitamente com o tempo. Substituindo as referências espaciais pelas categorias de passado, presente e futuro, Mercier operava aquilo que Koselleck concebia como uma mudança fundamental no status da utopia, isto é, a sua temporalização. ${ }^{33}$

Temporalizada e orientada ao futuro, a utopia de Mercier marcava também a efetivação de duas mudanças fundamentais na maneira de se conceber a composição de um romance utópico. A primeira seria, para Koselleck, a mudança na importância adquirida pela consciência do autor no processo de construção ficcional das utopias temporais. Diferentemente das utopias espaciais de outrora - nutridas pela possível verificabilidade daquilo que havia sido encontrado e observado no espaço -, as utopias futurísticas não apresentavam um contramundo real passível de comprovação empírica, tornando a consciência do autor a única referência para as informações apresentadas no texto: "Só ele (o autor), nenhuma pessoa além dele, é o artífice da utopia, que se transforma em ucronia. A realidade do futuro só existe como produto do escritor; o fundamento verificável do presente é abandonado". ${ }^{34}$

A segunda dessas mudanças seria a pressuposição, explícita ou implícita, de continuidades temporais. Se as antíteses dos contramundos espaciais de outrora podiam ser alcançadas por via marítima, estas agora precisavam ser comunicadas temporalmente. Assim, a dedução do futuro a partir do presente passou a exigir outros critérios de credibilidade, de

\footnotetext{
32 Op. cit., p.123.

33 Ibidem, p. 124-125.

34 Ibidem, p. 125.
} 
modo que as utopias passaram a utilizar pontos de contato crítico com o presente como o meio principal de construção dos seus contramundos futurísticos:

O que o futuro oferece é, em poucas palavras, a compensação da miséria atual, seja ela de natureza social, política, moral, literária ou qualquer outra que o coração sensível ou a razão esclarecida possam desejar. Expressado de outra forma: a perfeição fingida do contramundo até então espacial é temporalizada. Com isso, a utopia se insere diretamente nos objetivos dos filósofos iluministas. ${ }^{35}$

Era nesse ponto que Koselleck recuperava o eixo central da tese apresentada décadas antes no seu Crítica e crise, isto é, a ideia de que as modernas utopias seriam o produto da experiência histórica burguesa e da construção do mundo moral iluminista no século XVIII. Nesse sentido, a obra de Mercier era uma espécie de modelação literária do ideal rousseauniano de perfeitabilidade, convertendo o autor em uma espécie de precursor, na literatura, da filosofia iluminista da consciência. Posto em outros termos, o autor de $O$ ano 2440 trazia para a ficção elementos dos filosofemas progressistas que eram a marca da hipocrisia apolítica do Iluminismo tardio. Negando a dimensão do poder e estabelecendo o domínio da virtude burguesa, a utopia temporal de Mercier contribuía para legitimar, nas palavras de Koselleck, o reino do "terror virtuoso", caro à experiência histórica ocidental dos séculos subsequentes.

De modo a tratar criticamente das consequências desse lugar ocupado pela utopia na obra de Mercier e na de tantos outros autores modernos, na parte final de seu texto, Koselleck trazia à tona a análise de um trabalho que, em grande medida, poderia ser interpretado como uma espécie de sátira antitética das formas modernas de temporalização da utopia, isto é, o ensaio Os Buribuncos, de Carl Schmitt. ${ }^{36}$

Escrito à época do declínio do império de Guilherme II, o texto do jurista era interpretado como uma forma de paródia ao historicismo e à crença no progresso, podendo também ser lido, segundo Koselleck, como uma espécie de "utopia negativa" um tanto representativa do contexto cultural vivido pela Alemanha no pós-1918. Em sua sátira, Schmitt tratava da realidade ficcional dos buribuncos, indivíduos submetidos à lógica da buribuncologia, isto é, um tipo de ciência futurista que pressupunha uma correlação perfeita entre a escrita e a realidade. Na "buribuncasia real" de Schmitt cada ser humano era incentivado a escrever um diário, externando sua interioridade e propiciando o controle absoluto de sua personalidade. Funcionando de certa forma como uma filosofia lógico-histórica da identidade, a buribuncologia (e a buribuncasia como um todo) pressupunha tanto uma superação individual de cada escritor sobre si mesmo, como

\footnotetext{
35 KOSELLECK, Reinhart. Estratos do tempo: estudos sobre a história. Contraponto: Puc Rio, Rio de Janeiro, 2014, p. 126.

36 Há muitos motivos para acreditar que as posições de Schmitt expostas nesse texto são, em grande parte, as opiniões do próprio Koselleck. Além dos muitos diálogos diretos estabelecidos entre esses dois intelectuais desde os anos 1950, o próprio historiador admitia os vínculos do seu trabalho para com a obra de Schmitt, em especial na herança que sua crítica ao Iluminismo e que suas tentativas de desconstruir as aporias do pensamento político moderno possuíam em relação à obra do jurista. Para uma melhor discussão sobre os vínculos intelectuais entre Koselleck e Schmitt Cf. OLSEN, Niklas. Carl Schmitt, Reinhart Koselleck and the foundations of history and politics. History of European ideas, v. 37, n. 2, p. 197-208, 2011.
} 
um tipo de filosofia progressiva da história, baseada na evolução do espírito do mundo em um processo de autorreflexão propiciado pela escrita de diários:

Trata-se de um reino em que todas as pessoas escrevem um diário, onde a cada segundo registram tudo, a fim de se qualificar para a história. A história só se cumpre contanto e à medida que for registrada. A intensificação (...) transforma a atividade de escrever diários na única ação apta para a história. Ele desenvolveu um procedimento efetivo que, em uma hierarquia abrangente, produz um diário coletivo obrigatório da humanidade. Cópias de todos os diários são disponibilizadas para cada instância, e, por meio de índices de matérias e pessoas, torna-se possível exercer controle geral, desde o nível distrital até o central. ${ }^{37}$

Nessa sátira schmittiana, não haveria lugar para os oponentes da buribuncologia, sendo exercido o domínio total dos dissidentes, o controle dos progressistas e o banimento daqueles que se mostrassem incapazes de escrever um diário. Além disso, em nome da ciência e da tolerância, os buribuncos aboliram o medo da morte individual e a ideia de amor particular, tendo estes sido superados em nome da pura consciência e de uma autodeterminação geral: "Assim, o buribunco prossegue 'triunfante para a aurora da sua historicidade'". 38

Situado mais de um século após a publicação de $O$ ano 2440, a obra de Schmitt se revelava como uma espécie de réplica tardia à utopia futurística de Mercier. Parodiando a crença na capacidade do ser humano em perceber e em controlar a história por meio da consciência, Schmitt se voltava contra toda a fundamentação espiritual da modernidade, ironizando a temporalização da história na execução do ato de escrever:

Trata-se, evidentemente, de uma utopia consequentemente temporalizada, cuja força impulsionadora é a moderna filosofia da consciência. No que se refere ao passado, tudo é relativo. Mas levar o relativismo histórico absolutamente a sério significa elevar o buribunco ao espírito geral superior, que explora o futuro para si mesmo. Ele se empenha no - até então inaudito - enobrecimento próprio. ${ }^{39}$

Entre Mercier e Schmitt, a ingênua utopia futurística transformou-se em uma utopia temporal negativa. O elemento comum entre as duas utopias seria a escrita, veículo social da filosofia burguesa da história e do processo de temporalização da linguagem e da história. Longe de negar o papel e a importância da consciência no decurso da história, todavia, Koselleck esclarecia que o seu texto tinha o objetivo de refletir sobre as limitações das utopias em apreender a complexidade da experiência e das mais distintas manifestações da temporalidade na história:

A história real é, ao mesmo tempo, sempre mais e menos. Do ponto de vista ex post, é sempre diferente daquilo que somos capazes de imaginar. Por isso existem utopias, e justamente por isso elas são condenadas ao equívoco. Seu êxito costuma tender mais para a calamidade do que para a sorte que prometem. Mas

\footnotetext{
37 KOSELLECK, Reinhart. Estratos do tempo: estudos sobre a história. Contraponto: Puc Rio, Rio de Janeiro, 2014, p. 135.

38 Ibidem, p.137.

39 Ibidem, p. 136-137.
} 
não nos esqueçamos do conteúdo prognóstico das nossas duas utopias, que veio a ser confirmado pela história posterior. A utopia de Mercier se cumpriu, mesmo que de forma inversa à pretendida. A utopia de Carl Schmitt - apesar de sua função de advertência - também se cumpriu, de forma muito pior do que a parodiada. 40

Assim, acrescentando um tom de alerta à sua reflexão, Koselleck encerrava $A$ temporalização da utopia reiterando alguns elementos caros à sua teoria da história e à sua crítica da modernidade. Compreendendo tanto o fenômeno de irrupção do futuro na utopia, quanto as consequências desse processo de temporalização da linguagem e da experiência histórica, o historiador complementava suas críticas às formas modernas de interpretação da história, esclarecendo, desta vez, o papel cultural desempenhado pela utopia no encurtamento dos espaços de experiência, no alargamento dos horizontes de expectativa e no fenômeno da despolitização típicos da maneira burguesa de entendimento da realidade em tempos modernos.

Essa posição ficava ainda mais explícita em Sobre a história conceitual da utopia do tempo (1987), texto no qual Koselleck replicava a ideia central presente em seu escrito de 1982, apresentando maiores evidências empíricas a respeito de sua tese sobre a temporalização da utopia. ${ }^{41}$ Aqui o autor sintetizava em uma perspectiva mais pessoal a sua posição diante do tema que havia norteado suas preocupações intelectuais desde o início de sua carreira:

\begin{abstract}
Como historiador, proponho que todas as determinações futuras, sejam elas quais forem e de onde venham, sejam questionadas quanto à sua exequibilidade. A promessa de felicidade não me parece razão suficiente para propagar uma utopia e com ela legitimar o comportamento político. Mas devemos discutir racionalmente a respeito de todas as possibilidades de futuro. Quão grandes são as chances de realização de certos modelos, pode-se tentar determinar por meio de análises empírico-políticas. ${ }^{42}$
\end{abstract}

Reiterando suas posições anteriores, Koselleck defendia um maior esclarecimento teórico por parte da história disciplinar a fim de se delimitar o lugar de conceitos como utopia, pessimismo e otimismo enquanto "categorias subjetivas de experiência". Citando mais uma vez a possibilidade de extinção nuclear ainda presente daqueles anos finais da Guerra Fria, ele defendia uma fusão das éticas weberianas da "conviç̧ão" e da "responsabilidade" para,

\footnotetext{
40 KOSELLECK, Reinhart. Estratos do tempo: estudos sobre a história. Contraponto: Puc Rio, Rio de Janeiro, 2014, p. 138.

${ }^{41}$ Em um breve panorama da história do conceito de utopia desde Tomas Morus até a contemporaneidade, nesse escrito Koselleck lidava com os usos políticos do termo (ocorridos pela primeira vez durante as Revoluções Inglesa e Francesa dos séculos XVII e XVIII) e tratava das nuances positivas e pejorativas em seu significado até estabelecer um balanço sobre o lugar da utopia no que classificava como o etos pessimista das décadas finais do século XX (KOSELLECK, Reinhart, Zur Begriffsgeschichte der Zeitutopie In: KOSELLECK, Reinhart, Begriffsgeschichten: Studien zur Semantik und Pragmatik der politischen und sozialen Sprache, Frankfurt am Main: Suhrkamp Verlag, 2006). O texto (que havia sido publicado originalmente Utopien - Die Möglichkeiten des Unmöglichen, organizado por Hans-Jörg Braun) foi reeditado em 2006 na coletânea Histórias de conceitos (Begriffsgeschichten).
}

42 KOSELLECK, Reinhart. Futuro passado: contribuição à semântica dos tempos históricos. Rio de Janeiro: Contraponto: Ed. Puc Rio, 2006, p. 270. 
rejeitando mais uma vez os arroubos retóricos da modernidade utópica, responder de forma politicamente viável aos desafios apresentados no final do século XX: "Devemos ser pessimistas hoje sobre a ameaça nuclear? Ou otimistas? Nenhuma das alternativas pode ser politicamente ativa. Mas existem maneiras de esclarecer esse problema analiticamente até o ponto em que pelo menos se saiba o que fazer". ${ }^{43}$

Fica claro, portanto, que além de suas evidentes contribuições para as reflexões teóricas sobre a modernidade, essa crítica koselleckiana à utopia pode também servir como uma importante porta de entrada para ao menos dois relevantes debates da ordem do dia na historiografia: as discussões a respeito da crise contemporânea do tempo e os limites do projeto teórico de Koselleck no trato com as consequências dessa crise tanto nos centros do mundo ocidental quanto em suas periferias. Estes são os temas explorados em nosso próximo tópico.

\section{As possibilidades da crítica koselleckiana à utopia face à atual crise do tempo}

É seguro dizer que ao se preocupar em analisar as consequências do fenômeno da temporalização da utopia, Koselleck adiantava vários elementos de um dos mais importantes debates da historiografia profissional no presente século, isto é, a discussão a respeito dos limites da temporalidade moderna e da crise do tempo histórico na contemporaneidade. Bastante conhecidas nesse sentido são as hipóteses de nomes como Hans-Ulrich Gumbrecht e François Hartog, para quem o período das décadas finais do século XX (ou do pós-1945, para Gumbrecht) representou o esgotamento da orientação à futuridade característica da temporalidade moderna. Discordando da tese de Francis Fukuyama a respeito do "fim da história", tanto Gumbrecht ${ }^{44}$ quanto Hartog ${ }^{45}$ sustentam que, diante das diversas convulsões do século XX, a noção de história enquanto processo passou por severas rupturas em seu significado que contribuíram para a construção de uma experiência do tempo na qual o presente teria se sobreposto de maneira ampla sobre as formas de compreensão do passado e sobre as próprias maneiras de conceber o advento do futuro.

O fim do socialismo real, o boom memorialístico, os movimentos pós-colonialistas e o declínio das metanarrativas representariam, portanto, o início daquilo que Gumbrecht e Hartog denominam como "presentismo" ou "amplo presente", quando uma suspensão na produção do tempo histórico e uma separação radical entre experiência e expectativa passaram a marcar a relação dos homens e mulheres ocidentais com as limitadas possibilidades inerentes à história no início do século XXI. O temor em relação ao futuro, a paralisia diante dos excessos do

43 KOSELLECK, Reinhart, Zur Begriffsgeschichte der Zeitutopie In: KOSELLECK, Reinhart, Begriffsgeschichten: Studien zur Semantik und Pragmatik der politischen und sozialen Sprache, Frankfurt am Main: Suhrkamp Verlag, 2006, p. 272-273.

44 GUMBRECHT, Hans Ulrich. Depois de 1945: latência como origem do presente. Trad. Ana Isabel Soares. São Paulo: Ed. UNESP, 2014, p. 131.

45 HARTOG, François. Regimes de historicidade: presentismo e experiências do tempo. Belo Horizonte: Autêntica, 2013, p. 20. 
passado, as dúvidas em relação ao sentido da história e a prisão em um amplo presente seriam, portanto, marcas da crise vivida pela consciência histórica ocidental nas primeiras décadas do presente século. ${ }^{46}$

Mais produtivo do que apontar para a óbvia influência da crítica koselleckiana à utopia sobre essa hipótese é analisar a maneira como o próprio historiador alemão buscou responder aos desafios dessa crise da temporalidade moderna que, como visto, era anunciada em seu trabalho desde muito cedo. Para tanto é necessário que nos debrucemos não mais sobre a epistemologia do historiador, mas sobre a sua ontologia. E conforme mencionado em nossa introdução, esta é representada principalmente pela teoria koselleckiana dos estratos do tempo, sendo este o elemento fundamental de sua proposta ético-política e parte central de sua solução para a crise da temporalidade moderna.

Em sua tese a respeito da existência de distintos Estratos do tempo, ${ }^{47}$ Koselleck pretendia esclarecer que, longe de representar uma substância massiva que se move de um período a outro, o entendimento dos homens sobre o passado e sobre a história seria constituído por uma multiplicidade de camadas temporais dotadas de durações próprias, exclusivas e impossíveis de serem mensuradas a partir de um padrão temporal apriorístico. Utilizando uma metáfora geológica, os estratos do tempo representariam diversos planos, com durações diferentes e origens distintas, mas que apesar disso estariam presentes e atuariam simultaneamente. Essa sensibilidade diante da dinâmica expressa por distintas temporalidades seria a chave para se destrinchar o fenômeno da simultaneidade do não simultâneo, revelando diacronias ou sincronias existentes em contextos históricos completamente heterogêneos: "O proveito de uma teoria dos estratos do tempo consiste em sua capacidade de medir diferentes velocidades, acelerações ou atrasos, tornando visíveis os diferentes modos de mudança, que exibem grande complexidade temporal". 48

Assim, os estratos do tempo de Koselleck realizariam uma espécie de corte vertical através desse tempo geológico, sendo capazes de revelar as diacronias e as sincronias escamoteadas - quase sempre de forma violenta - pela lógica moderna de se ordenar o tempo histórico: "A proposta de diferentes estratos do tempo permite tratar de diferentes velocidades de mudança sem cair na falsa alternativa entre decursos temporais lineares ou circulares". 49

Problematizando e desnaturalizando a temporalidade estabelecida pela experiência da modernidade, essa era uma importante contribuição para se desconstruir a percepção da história como um processo homogêneo e singular, favorecendo a emergência de formas mais plurais de

\footnotetext{
46 Como podemos atestar nos seguintes trabalhos: GUMBRECHT, Hans Ulrich. Depois de 1945: latência como origem do presente. São Paulo: Ed. UNESP, 2014 e HARTOG, François. Regimes de historicidade: presentismo e experiências do tempo. Belo Horizonte: Autêntica, 2013.

47 KOSELLECK, Reinhart. Estratos do tempo: estudos sobre a história. Contraponto: Puc Rio, Rio de Janeiro, 2014.

48 Ibidem, p. 22.

49 Ibidem, p. 25.
} 
compreensão da história e de suas possibilidades tanto no campo da teoria quanto nos termos de uma práxis histórico-política mais democrática.

Sendo orientada à alteridade, essa teoria dos estratos do tempo prezava pela compreensão de dinâmicas temporais distintas daquela estabelecida unicamente a partir da experiência europeia com a modernidade. ${ }^{50}$ Não é de se estranhar, portanto que a ontologia koselleckiana tenha, em grande medida, influenciado o surgimento, nas últimas décadas, de uma série de esforços pela superação da antiga maneira singular de conceber a história e a ideia de tempo no mundo ocidental. Abrindo o pensamento histórico a novas e mais plurais maneiras de se conceber as categorias do tempo, essa ontologia certamente pôde se colocar como uma interessante via para se fugir das amarras causadas pelo esgotamento da antiga percepção temporal inerente ao moderno conceito de história.

De todo modo, sustentar que a hipótese de Koselleck foi capaz de oferecer soluções definitivas para a atual crise do tempo significa tratar apenas de uma parte do problema, ignorando o quanto a ontologia e a epistemologia koselleckianas encontram-se ainda ancoradas na mesma estrutura temporal moderna criticada pelo autor de Estratos do tempo. Esse paradoxo foi percebido, por exemplo, por Zoltán Boldizsár Simon, para quem a teoria koselleckiana sobre a mudança histórica continua a reproduzir a mesma dinâmica associada ao conceito de história como um singular coletivo. Simon nota que mesmo mitigando e permitindo uma compreensão mais complexa do tempo histórico, as duas constantes antropológicas da meta-história de Koselleck - isto é, espaço de experiência e horizonte de expectativa - continuam a situar as condições de possibilidade da mudança histórica em uma dinâmica de continuidade entre passado, presente e futuro. Dito de outro modo, por mais tênue que seja a distância entre experiência e expectativa, esta sempre dirá respeito à mudança processual operada por um sujeito ontológico cujo passado e futuro serão analisados com a finalidade de compreender a sua situação no presente. ${ }^{51}$

Além de epistemologicamente limitada pela estrutura temporal cuja crítica constituiu-se como norte de toda a carreira do historiador, a teoria de Koselleck não abarca uma compreensão de temporalidades distintas daquela operada a partir da experiência moderna. Nos termos de Simon isso significa que, circunscrevendo-se ainda à história entendia como um processo, o pensamento de Koselleck não é capaz de compreender a maneira como ao menos desde a segunda metade do século XX as sociedades ocidentais têm experimentado a mudança histórica, isto é, de forma não-processual, descontínua e inaudita. Desde o pós-1945 assistiu-se à emergência de uma série de desafios no âmbito tecnológico e ambiental que contribuíram para mudar radicalmente a antiga relação moderna entre experiência e expectativa, de modo que a possibilidade de mudanças sem precedentes (com a chance real de extinção da humanidade ou do próprio conceito de ser humano) limitou consideravelmente as formas de compreensão da

\footnotetext{
50 ANKERSMIT, Frank. Koselleck on 'histories' versus 'History' or: historical ontology versus historical epistemology. 2nd INTH Conference: The Practical Past, UFOP, 2016, p. 5.

${ }^{51}$ SIMON, Zoltán B. History in Times of Unprecedented Change: A Theory for the 21st Century. Bloomsbury Academic, London, 2019, p. 56-57.
} 
mudança histórica no Ocidente. Nesse sentido, com o agravante de estar limitada ao âmbito sócio-político, a proposta de Koselleck não teria condições de tratar desses que se tornaram alguns dos aspectos mais decisivos para o entendimento da sensibilidade histórica e da própria ideia de mudança histórica no século XXI: o risco de extinção nuclear, as mudanças climáticas antropogênicas, a tecnologia associada à inteligência artificial, a bioengenharia, 0 transhumanismo, etc. 52

Essas limitações do projeto epistemológico de Koselleck se agravam quando deparadas com um desafio adicional: a sua aplicabilidade em realidades distintas do contexto ocidental que serve como base de sua ontologia. Em outras palavras, tendo sido pensada a partir da experiência histórica centro-europeia, a teoria de Koselleck encontra distintos obstáculos quando projetada sobre o mundo não-europeu ou não-ocidental. De fato, essa é uma lacuna já percebida pela própria historiografia do velho continente, que tem observado, por exemplo, o quanto o modelo do Sattelzeit é problemático quando aplicado a realidades nacionais europeias um tanto distintas do contexto alemão privilegiado por Koselleck. ${ }^{53}$ E embora uma solução tenha sido buscada ao se focar menos na periodização e mais na análise comparada dos processos de aceleração semântica descritos na teoria da modernidade de Koselleck (utilizando-se, por exemplo, do já mencionado fenômeno da temporalização como parâmetro comparativo), problemas associados à relação centro-periferia no interior da própria Europa, além das armadilhas associadas à vernacularização, à tradução e à mutabilidade dos conceitos em contextos transnacionais continuam a impor desafios para os historiadores conceituais no continente europeu. ${ }^{54}$

Já no contexto Ibero-Americano a adaptação da teoria da história de Koselleck adquiriu proeminência principalmente a partir do já mencionado projeto Iberconceptos. $O$ fato de envolver uma realidade ainda mais ampla e complexa em termos de relações de poder e de circulação de ideias fez do Iberconceptos uma das mais profícuas fontes de debate nos últimos anos sobre a aplicabilidade da teoria koselleckiana para além do espaço de experiência europeu. Autores envolvidos no projeto têm realizado análises comparadas do desenvolvimento de conceitos chave na região para demonstrar, por exemplo, como a experiência latino-americana com a modernidade não representou um mero reflexo tardio do caso europeu, mas sim a expressão de formas específicas da experiência temporal no ambiente sócio-político posterior aos movimentos independentistas na América Latina. ${ }^{55}$ Isso tem fomentado reflexões sobre

\footnotetext{
52 SIMON, Zoltán B. History in Times of Unprecedented Change: A Theory for the 21st Century. Bloomsbury Academic, London, 2019, p. 4.

53 BOER, Pim den. 'National Concepts, Transnational Concepts: Begriffsgeschichte Beyond Conceptual Nationalism', In: FERNÁNDEZ-SEBASTIÁN, J (ed.). Political Concepts and Time: New Approaches to Conceptual History. Santander: Cantabria University Press, 2011, p. 210.

54 STEINMETZ, Willibald; FREEDEN, Michael. Introduction. Conceptual History: Challenges, Conundrums, Complexities In: STEINMETZ, Willibald; FREEDEN, Michael; FERNÁNDEZ-SEBASTIÁN, Javier (Ed.). Conceptual history in the European space. New York, Berghahn Books, 2017.
}

55 Sobre o assunto, ver: ARAUJO, V. L.; Pimenta, João Paulo G. História. Ler História (Lisboa), v. 55, p. 8396, 2008 e também ZERMEÑO PADILLA, Guillermo. Historia, experiencia y modernidad en Iberoamerica, 
como o advento da modernidade não pode ser entendido como mero processo de expansão unilateral da experiência europeia pelo globo, mas sim como a construção compartilhada de uma experiência com o tempo, na qual as antigas colônias do Novo Mundo desempenharam um papel fundamental na sedimentação do repertório semântico comum às formas modernas de se relacionar passado, presente e futuro nas periferias, assim como nos centros do mundo globalizado. ${ }^{56}$

Mesmo reconhecendo os ganhos trazidos pela perspectiva da história dos conceitos para a historiografia local, entretanto, o alcance da epistemologia koselleckiana para lidar com questões marcadamente latino-americanas tem sido também alvo de questionamentos. Quem aponta para alguns desses limites é o próprio Javier Fernández Sebastián, um dos fundadores do Iberconceptos e o principal coordenador do projeto na Espanha. Ele percebe que mesmo pautada em Heidegger, a ontologia de Koselleck continua presa às balizas neokantianas de entendimento das categorias de tempo e espaço características da modernidade, possuindo, portanto, uma série de pontos cegos no que diz respeito ao trato com cosmovisões alheias ao cânone científico ocidental. Citando o trabalho de Serge Gruzinski, ${ }^{57}$ Sebastián menciona como diversas culturas indígenas pré-colombianas não pensavam o mundo nos termos de uma temporalidade, carecendo da distinção de espaço/tempo e, portanto, revelando o quanto a pretensão totalizante dos universais antropológicos de Koselleck circunscreve-se a um tipo bastante específico de ser humano: o ocidental-moderno. Nesses termos, restaria aos historiadores concentrar-se no processo de difusão da história e de historicização sistemática do mundo, a fim de compreender como esse processo de "colonização do tempo" logrou impor sua forma de temporalidade e sua concepção de história sobre outros modelos de cultura e sociedade. ${ }^{58}$

Uma posição diferente sobre o mesmo tema é defendida por Hagen Schulz-Forberg, editor de um volume sobre a história global dos conceitos na Ásia, 59 para quem a aplicação da hipótese de Koselleck não passa pela simples compreensão do processo de expansão e adaptação passiva da temporalidade moderna por sujeitos históricos não-ocidentais, mas sim pela expansão da própria categoria de espaço de experiência de modo a se considerar os sujeitos históricos como

1750-1850. Almanack Braziliense. São Paulo: Instituto de Estudos Brasileiros da Universidade de São Paulo, n.7, maio de 2008.

56 SANTOS, Pedro Afonso Cristovão dos; NICODEMO, Thiago Lima; PEREIRA, Mateus Henrique de Faria. Historiografias periféricas em perspectiva global ou transnacional: eurocentrismo em questão. Estudos Históricos, v. 30, p. 161-186, 2017, p. 172-173.

57 Cf. NEVES, Guilherme Pereira das; MONTEIRO, Rodrigo Bentes; IEGELSKI, Francine. Iberconceptos, historia conceptual, teoría de la historia -Entrevista a Javier Fernández Sebastián (Parte I). Tempo, Niterói , Vol.24, n. 3, 2018, p. 687-700.

58 Ibidem, p. 699-700.

59 SCHULZ-FORBERG, Hagen. A Global Conceptual History of Asia, 1860-1940: Perspectives in Economic and Social History. New York: Pickering \& Chatto, 2014. 
agentes ativos em uma multiplicidade de níveis e possibilidades de atuação. ${ }^{60} \mathrm{Na}$ esteira da crítica pós-colonial, ${ }^{61}$ do giro espacial ${ }^{62}$ e da transnacionalização da historiografia fomentadas pela assim chamada global history, 63 Schulz-Forberg propõe complementar a noção koselleckiana de estratos do tempo com o que ele denomina como "estratos espaciais" (Raumschichten), isto é, a forma como as espacializações interagem, se sobrepõem e geram tensões na maneira de agir e de interpretar a realidade entre os diferentes atores tanto em contextos locais, quanto em dinâmicas globais e transnacionais. Dessa interação entre temporalidade e territorialidade, o autor acredita poder complementar o esforço de Koselleck pela quebra da dicotomia cíclico-linear do tempo, através de uma ruptura com formas nacionais e etnocêntricas de se imaginar os territórios. Relacionando os estratos do tempo aos estratos espaciais e atribuindo proeminência à agência dos próprios sujeitos históricos, Schulz-Forberg defende, portanto, uma história global indutiva baseada em estudos de caso como forma de superar os limites etnocêntricos da teoria da história de Koselleck. ${ }^{64}$

Embora o espaço do presente artigo não permita que analisemos a viabilidade de projetos como o de Schulz-Forberg ou as nuances existentes nas posições dos muitos autores envolvidos no Iberconceptos, é possível, entretanto, que essas propostas sirvam como referência para que retomemos a questão posta no início de nossa digressão. Afinal, diante de tais limitações, a agenda teórica de Koselleck pode ainda oferecer subterfúgios para que pensemos em superar a atual crise do tempo nas periferias do mundo globalizado? Dito de outro modo: é possível extrair da crítica à utopia e da ontologia koselleckianas elementos para que retomemos uma agenda

60 SCHULZ-FORBERG, Hagen. The Spatial and Temporal Layers of Global History: A Reflection on Global Conceptual History through Expanding Reinhart Koselleck's" Zeitschichten" into Global Spaces. Historical Social Research/Historische Sozialforschung, Vol. 38, no 145, p. 40-58, 2013, p. 43.

61 Os estudos pós-coloniais reposicionaram métodos, teorias e perspectivas utilizadas para estudar locais periféricos. A partir desta nova perspectiva, essa abordagem teórica problematiza postulados criados a partir de pensamentos coloniais e que continuam a fornecer padrões e chaves de leitura para as realidades europeias e não-europeias até os dias atuais. Em outras palavras, os poderes assimétricos e os modos hierárquicos de representação que produziram modelos de pensamentos estereotipados e distorcidos nas duas pontas, passaram a ser reconfigurados a partir dessa tendência de estudos. Sobre o assunto, ver: Chakrabarty, Dipesh: Provincializing Europe: Postcolonial Thought and Historical Difference, Princeton, NJ 2000; Said, Edward: Orientalism, New York, 1978.

62 O giro espacial, iniciado na década de 1970, questiona os tradicionais conceitos de espacialidade e sua relação com o tempo. Assim, especialistas passaram a refletir sobre as mudanças de ordem espacial e problematizar pelo menos dois aspectos elementares na produção do conhecimento nas humanidades: o aumento da proximidade e o encurtamento dos espaços geográficos por causa da integração internacional, bem como, organizações espaciais que reproduziam a exclusão social e emergiram em decorrência da integração (MIDDELL, Matthias; NAUMANN, Katja. Global history and the spatial turn: from the impact of area studies to the study of critical junctures of globalization. Journal of Global History, 5, p. 149-170, 2010, p. 154-155).

63 Global History é uma abordagem historiográfica iniciada no Pós-Guerra Fria e que ganhou bastante força na historiografia das últimas décadas. Essa tendência historiográfica pode ser vista como uma resposta aos desafios sociais e à demanda por narrativas mais inclusivas, menos restritas às tradicionais perspectivas nacionalistas na produção histórica sobre o passado em alguns países. A integração internacional dos intelectuais experimentada pelo menos desde os anos 1990 contribui para a superação das visões eurocêntricas e ocidentalistas da história, já que diversas correntes historiográficas inseridas nesse campo trazem novos olhares para a maneira de se escrever história em diferentes lugares. Para saber mais, ver: CONRAD, S. What is Global History? New Jersey, Princeton University Press, 2016.

${ }^{64}$ Ibidem, p. 54. 
positiva para a nossa historiografia na contemporaneidade? Tentamos oferecer caminhos para responder a essas questões em nossas considerações finais.

\section{Considerações finais}

Transcorridas duas décadas desde a publicação da primeira obra de Koselleck em língua portuguesa, ${ }^{65}$ muitos tem sido os esforços de nossa historiografia em interpretar elementos do trabalho desse historiador alemão à luz de problemas caros à história e à escrita da história no Brasil e no mundo Ibero-americano como um todo. Não distando deste propósito, no presente artigo tivemos o objetivo de contribuir em tal direção, apontando, sobretudo, para a importância da crítica koselleckiana à ideia de utopia no cerne de sua teoria da história e de sua crítica à modernidade. Característica da trajetória intelectual do historiador ainda pouco visitada pelos intérpretes de sua obra, a crítica à utopia pode ser entendida como uma das chaves interpretativas de boa parte do legado de Koselleck, ${ }^{66}$ tendo figurado, implícita ou explicitamente, em alguns dos seus mais importantes trabalhos ao menos desde a década de 1950.

Como visamos demonstrar nas páginas acima, o olhar crítico de Koselleck em relação às armadilhas do utopismo esteve intimamente associado à sua intepretação do advento da modernidade como um processo de temporalização da história no mundo ocidental, com o consequente encurtamento dos espaços de experiência e o alargamento dos horizontes de expectativas ocorrido principalmente a partir do século XVIII europeu. Mesmo antes de desenvolver essa teoria dos tempos modernos, entretanto, o historiador já havia demonstrado uma preocupação com o problema da utopia em trabalhos como Crítica e crise, quando a questão do utopismo político foi por ele associada à crítica ao absolutismo, à ascensão da burguesia e, sobretudo, ao fenômeno da despolitização ocorrido durante o século das luzes na Europa.

Apesar de central em sua teoria da história e em sua crítica da modernidade, todavia, Koselleck demoraria a tratar diretamente do problema da utopia, o fazendo apenas nos anos 1980 com a publicação de $A$ temporalização da utopia e Sobre a história conceitual da utopia do tempo. Vimos que nos textos em questão, o historiador buscava demonstrar como, no amplo contexto europeu de modernização e de temporalização das experiências históricas, a escrita de utopias incorporou a ideia de futuro, principalmente da segunda metade do século XVIII em diante. Compreendendo esse fenômeno a partir de uma perspectiva crítica (com a análise de

\footnotetext{
65 Crítica e crise foi traduzido por Luciana Villas-Boas Castelo-Branco e publicado em 1999 pelas editoras Eduerj e Contraponto.

66 Nesse ponto é possível concordar com a perspectiva explorada, sobretudo, por Niklas Olsen. Olsen desenvolve uma interpretação primeiramente oferecida por Jacob Taubes nos anos 1970, sustentando que toda a produção acadêmica de Koselleck pode ser lida como uma série de tentativas no sentido de minar ideias de história no singular, teorizando histórias no plural, isto é, "um ponto de vista estável, nãorelativista a partir do qual a mudança histórica pudesse ser descrita e de onde um parâmetro de julgamento pudesse ser estabelecido, discutindo-se o passado e o presente sem que se caísse nas armadilhas do utopismo" (OLSEN, Niklas. History in the Plural: an introduction to the work of Reinhart Koselleck. New York: Berghahn Books, 2012, p. 5).
} 
uma paródia anti-utópica escrita por Carl Schmitt no início do século XX), Koselleck fundia dois elementos de sua teoria da história presentes em sua obra desde o início de sua carreia, quais sejam, sua análise da modernidade (explícita em sua tese sobre a temporalização e sobre a despolitização) e sua crítica à utopia (por ele associada ao surgimento das modernas filosofias da história).

Longe de esgotar as possibilidades de análise do tema, essa abordagem da crítica à utopia na obra de Koselleck pretendeu abrir mais uma chave interpretativa em relação ao trabalho do autor da história dos conceitos, fomentando, de igual modo, uma reflexão sobre como as suas posições se relacionam com a emergência da atual crise do tempo, bem como às possibilidades de superação dessa crise a partir da retomada de uma agenda positiva para a disciplina histórica no presente século. Afinal não são poucos os autores que têm falado da necessidade de se pensar para além da atual estagnação presentista do tempo histórico, visando uma maior abertura da disciplina às demandas contemporâneas por reflexões a respeito do futuro. ${ }^{67}$

É na esteira de tais discussões que intelectuais como Ewa Domanska têm defendido a agenda das assim chamadas "humanidades afirmativas", voltadas à construção de utopias realistas associadas não mais a não-lugares imaginados, mas sim às potencialidades e demandas locais do aqui e do agora. Contrária à restrição dessa agenda às epistemologias europeias, Domanska propõe uma associação entre a construção dessas novas utopias realistas à ideia de relações interpessoais dos povos africanos, bem como aos princípios comunitários de coexistência entre humanos e natureza presentes na cosmovisão de diversas tribos indígenas latino-americanas. ${ }^{68}$ Entendendo as humanidades como "saberes de convivência em conflito" (visando formar um saber inclusivo sobre o passado, do qual fazem parte as humanidades, ao lado das ciências da vida e dos vários modos indígenas de saber) a historiadora pretende desenvolver uma perspectiva sobre a história que seja orientada para o futuro e que atue neutralizando tanto o antropocentrismo quanto o eurocentrismo, que, até agora, têm sido os modos dominantes de construção do conhecimento sobre o mundo e sobre a humanidade. ${ }^{69}$

A iniciativa pela reinvenção da utopia nos termos realistas de Domanska oferece um bom parâmetro para que respondamos afinal o nosso questionamento sobre o alcance das ideias de Koslleck diante desse tipo de debate. Conforme demonstrado nas páginas acima, a proposta

\footnotetext{
67 Podemos identificar traços dessa pretensão, por exemplo, no objetivo de Jörn Rüsen em esclarecer a função orientadora da história através da ideia de matriz disciplinar, assim como o último foco de Hayden White na dimensão prática - o "passado prático" - existente no estudo do passado (RÜSEN, Jörn. History: Narration - Interpretation - Orientation. Berghahn, New York, 2005; WHITE, Hayden. The practical past. Northwestern: University Press, 2014). Mais recentemente Hartog visou também dar um passo além em sua tese sobre o presentismo, engrossando as fileiras daqueles interessados em pensar possíveis bases para voltar a se "acreditar na história" (HARTOG, François. Crer em história. Belo Horizonte: Autêntica, 2017, p. 9-10). O trabalho de Simon sobre a assim chamada "mudança inaudita", de igual maneira, é um exemplo ainda mais claro sobre essa tentativa de se repensar as possibilidades da ideia de mudança histórica no contexto contemporâneo (SIMON, Zoltán Boldizsár. History in Times of Unprecedented Change: A Theory for the 21st Century. Bloomsbury Publishing, 2019).

68 DOMANSKA, Ewa. Affirmative Humanities. Dějiny - teorie - kritika [history-theory-criticism], n. 1, 2018, p. 21.

${ }^{69}$ Ibidem, p. 18.
} 
koselleckiana possui a desvantagem de se basear em uma epistemologia cujos fundamentos ontológicos encontram-se pautados unicamente na dinâmica moderna de interpretação do tempo. Sendo assim, uma história conceitual assentada na teoria dos estratos do tempo se mostraria incompatível, por exemplo, com uma proposta das humanidades afirmativas cuja referência para pensar o devir histórico partisse não de uma ontologia moderna-ocidental, mas dos modos de saber dos povos africanos ou das tribos originárias latino-americanas. Além disso, vimos que a teoria da história de Koselleck se circunscreve à esfera sócio-política de entendimento de uma temporalidade moderna contínua e processual, mostrando-se limitada no trato com as dimensões da tecnologia e da ecologia, âmbitos centrais para se pensar a irrupção do futuro nesta que é considerada por muitos como uma forma inaudita (e portanto, nãomoderna e não processual) de se pensar a temporalidade no mundo contemporâneo. ${ }^{70}$

É possível concluir, portanto, que embora sirva como um importante ponto de partida para se pensar as fragilidades e as frestas a partir das quais é possível complexificar e atenuar os efeitos colaterais da temporalidade moderna, o projeto de Koselleck não é capaz, por si só, de oferecer as ferramentas necessárias para superarmos a atual crise do tempo. É necessário que, pensando a partir de nossa condição periférica, complementemos a teoria de Koselleck fazendo-a abarcar a experiência do "outro" da modernidade na América Latina. ${ }^{71}$ Ampliar e reinventar o cânone koselleckiano pela ótica dos oprimidos e marginalizados de nosso continente talvez seja um dos caminhos para que possamos finalmente restabelecer o lugar de novas utopias-realistas no horizonte da nossa historiografia nesse início de século XXI.

\footnotetext{
70 SIMON, Zoltán Boldizsár. History in Times of Unprecedented Change: A Theory for the 21st Century. Bloomsbury Publishing, 2019.

${ }^{71}$ DUSSEL, Enrique. 1492 - O encobrimento do outro: a origem do mito da modernidade. Conferências de Frankfurt. Trad. Jaime A. Clasen. Petrópolis, Rio de Janeiro: Vozes, 1993.
} 


\section{Referências}

\section{Bibliografia}

ARAUJO, Valdei Lopes de \& PIMENTA, João Paulo G. História (conceito de). In: FERES JÚNIOR, João (org. ). Léxico da história dos conceitos políticos do Brasil. Belo Horizonte: Editora da UFMG, 2009.

ABREU, Cesaltina. A transformação da história em processo: Da perspectiva utópica da filosofia da história à Revolução Francesa de Koselleck. Mulemba [Online], v. 6, n. 11, 2016.

ANKERSMIT, Frank. Koselleck on 'histories' versus 'History' or: historical ontology versus historical epistemology. 2nd INTH Conference: The Practical Past, UFOP, 2016.

BOER, Pim den. 'National Concepts, Transnational Concepts: Begriffsgeschichte Beyond Conceptual Nationalism', In: FERNÁNDEZ-SEBASTIÁN, J (ed.). Political Concepts and Time: New Approaches to Conceptual History. Santander: Cantabria University Press, 2011.

CONRAD, Sebastian. What is Global History? New Jersey, Princeton University Press, 2016.

DOMANSKA, Ewa. Affirmative Humanities. Dějiny - teorie - kritika [history-theory-criticism], no. 1 , p. 9-26, 2018.

DUARTE, J. A. D. Tempo e Crise na Teoria da Modernidade de Reinhart Koselleck. História da Historiografia, v. 8, p. 70-90, 2012.

DUSSEL, Enrique. 1492 - O encobrimento do outro: a origem do mito da modernidade. Conferências de Frankfurt. Petrópolis, Rio de Janeiro: Vozes, 1993.

FERES JÚNIOR, João; JASMIN, Marcelo G. Introdução: trajetórias e contatos da história conceitual In: FERES JÚNIOR, João; JASMIN, Marcelo G. (Org.). História dos Conceitos: diálogos transatlânticos. Rio de Janeiro: Edições Loyola, 2007.

GOUREVITCH, Victor. Foreword. In: REINHART, Koselleck. Critique and Crisis: Enlightenment and the Pathogenesis of Modern Society. The MIT Press, Cambridge, Massachusetts, 1988.

GUMBRECHT, Hans Ulrich. Nosso amplo presente: o tempo e a cultura contemporânea. Ed. Unesp, São Paulo, 2015.

GUMBRECHT, Hans Ulrich. Depois de 1945: latência como origem do presente. São Paulo: Ed. UNESP, 2014.

HARTOG, François. Crer em história. Belo Horizonte: Autêntica, 2017.

HARTOG, François. Regimes de historicidade: presentismo e experiências do tempo. Belo Horizonte: Autêntica, 2013.

HEIDEGgeR, M. Ser e tempo. Petrópolis, RJ: Vozes, 2013.

HÖLSCHER, Lucian. Utopie. In: BRUNNER, Otto; CONZE, Werner; KOSELLECK, Reinhart. Geschichtliche Grundbegriffe. Historisches Lexikon zur politisch-sozialen Sprache in Deutschland, v. 6, 1990. 
JUNG, Theo. Das Neue der Neuzeit ist ihre Zeit: Reinhart Kosellecks Theorie der Verzeitlichung und ihre Kritiker. Moderne Kulturwissenschaftliches Jahrbuch, n. 6, 2011.

NEVES, Guilherme Pereira das; MONTEIRO, Rodrigo Bentes; IEGELSKI, Francine. Iberconceptos, historia conceptual, teoría de la historia -Entrevista a Javier Fernández Sebastián (Parte I). Tempo, Niterói, v. 24, n. 3, p. 687-700, Dec. 2018.

KOSELLECK, Reinhart. Critique and Crisis: Enlightenment and the Pathogenesis of Modern Society. The MIT Press, Cambridge, Massachusetts, 1988.

KOSELLECK, Reinhart. Crítica e crise: uma contribuição à patogênese do mundo burguês. Eduerj, 1999.

KOSELLECK, Reinhart. A temporalização da utopia In: KOSELLECK, Reinhart. Estratos do tempo: estudos sobre a história. Contraponto: Ed. Puc Rio, Rio de Janeiro, 2014.

KOSELLECK, Reinhart. Estratos do tempo In: KOSELLECK, Reinhart. Estratos do tempo: estudos sobre a história. Contraponto: Ed. Puc Rio, Rio de Janeiro, 2014.

KOSELLECK, Reinhart. Futuro passado: contribuição à semântica dos tempos históricos. Rio de Janeiro: Contraponto: Ed. Puc Rio, 2006.

KOSELLECK, Reinhart, MEIER, Christian, GÜNTHER, Horst \& ENGELS, Odilo. O conceito de História. Autêntica, Belo Horizonte, 2013.

KOSELLECK, Reinhart. Un texto fundamental de Reinhart Koselleck: la introducción al Diccionario Histórico de Conceptos Político-Sociales Básicos en Lengua Alemana, seguida del prólogo de dicha obra (traduzido por Luis Fernández Torres). Anthropos, n, 223, Barcelona, 2009.

KOSELLECK, Reinhart, Zur Begriffsgeschichte der Zeitutopie In: KOSELLECK, Reinhart, Begriffsgeschichten: Studien zur Semantik und Pragmatik der politischen und sozialen Sprache, Frankfurt am Main: Suhrkamp Verlag, 2006.

MIDDELL, Matthias; NAUMANN, Katja. Global history and the spatial turn: from the impact of area studies to the study of critical junctures of globalization. Journal of Global History, 5, p. 149-170, 2010.

OLSEN, Niklas. Carl Schmitt, Reinhart Koselleck and the foundations of history and politics. History of European ideas, v. 37, n. 2, p. 197-208, 2011.

OLSEN, Niklas. History in the Plural: an introduction to the work of Reinhart Koselleck. New York: Berghahn Books, 2012.

RÜSEN, Jörn. History: Narration - Interpretation - Orientation. Berghahn, New York, 2005.

SANTOS, Pedro Afonso Cristovão dos; NICODEMO, Thiago Lima; PEREIRA, Mateus Henrique de Faria. Historiografias periféricas em perspectiva global ou transnacional: eurocentrismo em questão. Estudos Históricos, v. 30, p. 161-186, 2017.

SCHELSKY, Helmut. Die skeptische Generation: eine Soziologie der deutschen Jugend. Eugene Diederichs, 1957.

SCHULZ-FORBERG, Hagen. A global conceptual history of Asia, 1860-1940. Routledge, 2015.

SCHULZ-FORBERG, Hagen. The Spatial and Temporal Layers of Global History: A Reflection on Global Conceptual History through Expanding Reinhart Koselleck's" Zeitschichten" into Global Spaces. Historical Social Research/Historische Sozialforschung, Vol. 38, n 145, p. 40-58, 2013. 
SIMON, Zoltán Boldizsár. History in Times of Unprecedented Change: A Theory for the 21st Century. Bloomsbury Publishing, 2019.

STEINMETZ, Willibald; FREEDEN, Michael. Introduction. Conceptual History: Challenges, Conundrums, Complexities In: STEINMETZ, Willibald; FREEDEN, Michael; FERNÁNDEZSEBASTIÁN, Javier (Ed.). Conceptual history in the European space. Berghahn Books, 2017.

WHITE, Hayden. The practical past. Northwestern: University Press, 2014.

ZERMEÑO PADILLA, Guillermo. Historia, experiencia y modernidad en Iberoamerica, 17501850. Almanack Braziliense. São Paulo: Instituto de Estudos Brasileiros da Universidade de São Paulo, n.7, maio de 2008. 